\title{
CELLULOLYTIC POTENTIAL OF A NOVEL STRAIN OF PAENIBACILLUS SP. ISOLATED FROM THE ARMORED CATFISH PAROTOCINCLUS MACULICAUDA GUT
}

\section{André L. M. de Castro ${ }^{1}$, Renata E. Vollú ${ }^{2}$, Raquel S. Peixoto ${ }^{1}$, André L. Grigorevski-Lima ${ }^{3}$, Rosalie R. R. Coelho ${ }^{3}$, Elba P.} S. Bon ${ }^{4}$, Alexandre S. Rosado ${ }^{1}$, Lucy $\operatorname{Seldin}^{2} *$

${ }^{1}$ Laboratório de Ecologia Molecular Microbiana, Instituto de Microbiologia Paulo de Góes, Universidade Federal do Rio de Janeiro, Ilha do Fundão, RJ, Brasil; ${ }^{2}$ Laboratório de Genética Microbiana, Instituto de Microbiologia Paulo de Góes, Universidade Federal do Rio de Janeiro, Ilha do Fundão, RJ, Brasil; ${ }^{3}$ Laboratório de Biotecnologia de Actinomicetos, Instituto de Microbiologia Paulo de Góes, Universidade Federal do Rio de Janeiro, Ilha do Fundão, RJ, Brasil; ${ }^{4}$ Instituto de Química, Universidade Federal do Rio de Janeiro, Ilha do Fundão, RJ, Brasil.

Submitted: January 04, 2011; Approved: May 30, 2011.

\begin{abstract}
A cellulolytic bacterial strain, designated P118, isolated from the gut of the tropical fish Parotocinclus maculicauda was identified as belonging to the genus Paenibacillus based on phenotypic and chemotaxonomic characteristics and the 16S rRNA gene sequence. The novel strain was Gram-positive, spore-forming and rod-shaped. Catalase but not oxidase was produced. Carboxymethylcellulose was hydrolyzed but starch or gelatin was not. Acetoin production was negative whereas nitrate reduction and urease production were positive. Many carbohydrates served as carbon sources for growth. MK-7 was the predominant isoprenoid quinone. Anteiso- $\mathrm{C}_{15: 0}(38.73 \%)$ and $\mathrm{C}_{16: 0}(20.85 \%)$ were the dominant cellular fatty acids. Strain P118 was closely related to Paenibacillus amylolyticus NRRL NRS-290, P. pabuli HSCC 492, P. tundrae Ab10b, P. xylanexedens B22a, and P. tylopili MK2 with 98.3-98.8\% 16S rRNA gene sequence similarity. The results presented here suggest that strain P118 represents a novel species of the genus Paenibacillus and it is a potential strain for further studies concerning its role in the production of industrially important products from cellulosic biomass.
\end{abstract}

Key words: Bioprospection; Cellulose degradation; Paenibacillus sp.; Parotocinclus maculicauda; Taxonomy

\section{INTRODUCTION}

The armored catfish Parotocinclus maculicauda is a member of the Loricariidae family and the Hypoptopomatinae sub-family, formed by 16 genera and 79 species (27). Fish belonging to the species $P$. maculicauda are detritivorous, live well in rivers with clean water with a neutral to slightly acidic $\mathrm{pH}$ and in lower tropical temperatures, and are popularly known as Red Fin Dwarf Pleco. They are usually found in the south of Brazil (5). However, Leitão et al. (16) have also

*Corresponding Author. Mailing address: Laboratório de Genética Microbiana, Departamento de Microbiologia Geral, Instituto de Microbiologia Prof. Paulo de Góes (IMPPG), Universidade Federal do Rio de Janeiro, Centro de Ciências da Saúde, Bloco I, Ilha do Fundão, CEP 21941-590, Rio de Janeiro, Brasil.; Tel.: 55-21-2562.6741 Fax.: 55-21-2560.8344.; E-mail: 1seldin@micro.ufrj.br / lucy@seldin.com.br 
observed the presence of $P$. maculicauda in different coastal rivers of the Atlantic Forest. P. maculicauda shows a behavior based on grazing, being found near to the bottom of the creek on rocks, logs and submerged plants, scraping the periphyton matrix (4). The bacterial community found associated with this fish is almost unknown. However, it is well established that the microflora present in water influences directly the microorganisms found in the interior of the digestive tract of fish (9). Based on the kind of diet imposed to P. maculicauda, which consists mainly of plant material from allochthonous and autochthonous origins, it is expected the presence of cellulotytic bacteria in the fish gut.

Bioprospection is the systematic search of new sources of chemical compounds, genes, proteins, microorganisms and other products that have economic potential and can be found in biodiversity. Less than $1 \%$ of the existent microorganisms have been cultivated and characterized so far. Novel microorganisms obtained from poorly studied environments can bring new insights on novel genes and enzymes. In this context, the bacterial community present in the digestive trait of $P$. maculicauda can be identified providing survival and competencies to its host. Among the different isolates obtained, specific bacterial populations can be selected for one specific characteristic of interest. In this study, among different bacterial isolates, a cellulolytic strain denoted P118 was isolated from the gut of $P$. maculicauda. Therefore, our goal was to identify and characterize this isolate and to demonstrate its potential for cellulose degradation. Biochemical and molecular data obtained suggest that the isolate belongs to a new species of Paenibacillus.

\section{MATERIALS AND METHODS}

\section{Fish samples}

Twenty fishes belonging to the $P$. maculicauda species were obtained from Mato Grosso river (Saquarema, Rio de Janeiro, Brazil) located at $22^{\circ} 533^{\prime} 32.5^{\prime \prime} \mathrm{S}$ and $42^{\circ} 38^{\prime} 59.8^{\prime \prime} \mathrm{W}$.
This river has $12 \mathrm{~km}$ of extension, 2 to $4 \mathrm{~m}$ of width and at least 20 inches of depth. The fishes were collected manually using trawls and immediately taken to the laboratory for dissection in aseptic conditions.

\section{Isolation of bacterial strains}

The food content from the digestive tract of the different fish samples was transferred to sterilized tubes and portions of $200 \mathrm{mg}$ were mixed with $1.8 \mathrm{ml}$ of saline. This mixture was diluted in saline and plated in triplicate onto Trypticase Soy Broth (TSB, Difco) - agar (1.2\%). After $48 \mathrm{~h}$ of incubation at $32^{\circ} \mathrm{C}$, different colonies were selected based on their morphotypes. The different isolates were cultivated and maintained in slants with the same medium at $32^{\circ} \mathrm{C}$ and room temperature, respectively.

\section{Detection of cellulolytic activity}

The different isolates were inoculated as a $5 \mu \mathrm{l}$-spot on the surface of a carboxymethylcellulose (CMC) containing medium (CMC, 10g; $\mathrm{KH}_{2} \mathrm{PO}_{4}, 4 \mathrm{~g} ; \mathrm{Na}_{2} \mathrm{HPO}_{4}, 4 \mathrm{~g}$; tryptone, $2 \mathrm{~g}$; $\mathrm{MgSO}_{4} 7 \mathrm{H}_{2} \mathrm{O}, 0.2 \mathrm{~g} ; \mathrm{CaCl}_{2}, 0.001 \mathrm{~g} ; \mathrm{FeSO}_{4} .7 \mathrm{H}_{2} \mathrm{O}, 0.004 \mathrm{~g}$; agar $15 \mathrm{~g}, 11$ distilled water, $\mathrm{pH} 7.0$; (3)). After incubation at $32^{\circ} \mathrm{C}$ for $48 \mathrm{~h}$, the bacterial cells were flooded with $5 \mathrm{ml}$ of congo red $(0.1 \%)$ and washed with $\mathrm{NaCl}(1 \%)$. The cellulolytic strains were identified by the formation of a clear halo around the bacterial growth (3).

\section{Cellulase production}

A pre-inoculum of the selected strain (P118) was prepared in a $250 \mathrm{ml}$ Erlenmeyer flask containing $50 \mathrm{ml}$ of TSB. This flask was inoculated with a loop full of the strain grown in a TSB agar-containing plate and incubated at $32^{\circ} \mathrm{C}$ under agitation (rotator shaker $200 \mathrm{rpm}$ ) for 24 hours. Strain P118 was then inoculated ( $25 \mu \mathrm{l}$ of the pre-inoculum) in different flasks containing $25 \mathrm{ml}$ of CMC medium (without tryptone), $\mathrm{pH} 7.0$, and was incubated at the same conditions for 5 days. Samples were collected daily and the whole content of each 
flask (filtrate obtained after filtration through glass microfiber filter - Millipore) was used for determining the cellulase activity at different periods of time. Results were expressed as the average of two replicates.

Carboxymethylcellulase (CMCase) activity was assayed by measuring the release of reducing sugars in a reaction mixture of $1 \mathrm{ml}$ of the crude enzyme and $1 \mathrm{ml}$ of $4 \%(\mathrm{w} / \mathrm{v})$ CMC suspension in $50 \mathrm{mM}$ sodium citrate buffer $(\mathrm{pH} 4.8)$ incubated at $50^{\circ} \mathrm{C}$ for $10 \mathrm{~min}$ (6). Reducing sugars were assayed by the dinitrosalicylic acid (DNS) method (18). One unit (U) of CMCase activity corresponded to $1 \mu \mathrm{mol}$ of glucose equivalent released per minute under the assay conditions.

\section{Morphological, physiological and biochemical characterization}

Cellular morphology, form and position of spores and swelling of the sporangia were observed on crystal violetstained smears by using a Zeiss phase-contrast microscope. Cellular motility was observed in fresh wet mounts of young (24-h) bacterial cultures in TSB.

Most biochemical tests were performed by using the methods and media described by Gordon et al. (7). For all tests that required complex media (such as temperature and $\mathrm{pH}$ range of growth, growth inhibition in the presence of $\mathrm{NaCl}$ and in $\mathrm{pH} \mathrm{5.7,} \mathrm{hydrolysis} \mathrm{of} \mathrm{starch,} \mathrm{resistance} \mathrm{to} \mathrm{lysozyme} \mathrm{and}$ liquefaction of gelatin), TSB or TSB agar were employed. Growth under anaerobic conditions was determined after incubation for 7 days in anaerobic Gaspak jars (BBL) containing an atmosphere of $80 \% \mathrm{~N}_{2}, 10 \% \mathrm{CO}_{2}$ and $10 \% \mathrm{H}_{2}$. Catalase activity was determined by bubble production in a $3 \%$ (v/v) hydrogen peroxide solution.

Strains were also characterized by using API tests (API $50 \mathrm{CH}$ and 20E, bioMérieux) as described in Seldin and Penido (30) and in each manual. Data from API 50CH tests composed of 49 different carbohydrates were recorded as described previously (28).

Analysis of respiratory quinones and fatty acids were carried out by the Identification Service and Dr. Brian Tindall,
DSMZ, Braunschweig, Germany.

Preparation of genomic DNA, PCR amplification, 16S rRNA gene sequencing and phylogenetic analysis

Total DNA was extracted from the selected strain (P118) as described in Seldin and Dubnau (29). The procedure described by Massol-Deya et al. (17) was employed for PCR amplification of the 16S rRNA coding gene using the pair of universal primers ( $\mathrm{pA}$ and $\mathrm{pH})$. The amplification conditions were: a hot start $\left(2 \min 10 \mathrm{~s}\right.$ at $\left.92^{\circ} \mathrm{C}\right)$ and 35 cycles of $92^{\circ} \mathrm{C}(1$ $\min 10 \mathrm{~s}), 48^{\circ} \mathrm{C}(30 \mathrm{~s})$ and $72^{\circ} \mathrm{C}(2 \min 10 \mathrm{~s})$. A final extension step was run for $6 \min 10 \mathrm{~s}$ at $72^{\circ} \mathrm{C}$ and the reaction tubes were then cooled to $4^{\circ} \mathrm{C}$. DNA preparation and PCR products were visualized after electrophoresis respectively in $0.8 \%$ and $1.2 \%$ agarose gel in 1x TBE buffer (26).

PCR product of the $16 \mathrm{~S}$ rRNA coding gene from P118 was sequenced by using an ABI Prism 3100 automatic sequencer. All sequences were identified using the Blastn facility (www.ncbi.nlm.nih.gov/blast) of the National Center for Biotechnology Information with GenBank non-redundant database. The $16 \mathrm{~S}$ rRNA coding gene sequences of closely related strains were recovered from GenBank database and aligned with the sequences obtained in this study using the package software Clustal X (34). BioEdit version 7.0.5.3 (http://www.mbio.ncsu.edu/Bioedit/bioedit.html) was used for manual editing of the sequences.

Phylogenetic trees were constructed based on complete 16S rDNA sequences, using the Neighbor-Joining (NJ) method (25), whereas MEGA 4.1 software (15) was used to calculate pairwise p-distance values for $16 \mathrm{~S}$ rRNA gene sequences among the different species studied here.

\section{RESULTS AND DISCUSSION}

The production of industrially important products from cellulosic biomass needs the bioconversion of the cellulosic components into fermentable sugars. A variety of microorganisms may have the ability to degrade the cellulosic 
biomass to glucose monomers, and several efforts have been made to increase the production of cellulases through strain improvement. Some of these studies showed limited success (14) and the prospection of cellulolytic bacterial strains in singular environments has been cited in literature as an alternative approach for increasing cellulose production. For example, cellulose-degrading bacterial diversity was studied in an unusual environment like a weathered soil-like sample collected from the deep subsurface $(1.5 \mathrm{~km}$ depth) of the Homestake gold mine in Lead, South Dakota, USA (22). Therefore, the prospection of cellulolytic bacterial strains in the gut of Parotocinclus maculicauda, used in this study, can be of great importance and utility. Because of the diet imposed to $P$. maculicauda, constituted mainly of plant material, the presence of cellulolytic bacteria was expected.

The food content from the digestive trait of the different fish samples was used for bacterial isolation. Different colonies were selected based on their morphotypes and were tested for cellulolytic activity. Although different isolates showed tiny halos around the bacterial growth in CMC plates, only one strain (designed P118) showed a clear and reliable halo around its spot growth. Because of its cellulolytic potential, strain P118 was further characterized taxonomically and the CMCase activity measured at different periods of time.

P118 cells are rod shaped, they grow and form spores aerobically, and they are catalase positive but oxidase negative. After $24 \mathrm{~h}$ in TSB, they occur either singly or in short chains and are motile. The cells are $2.9 \pm 0.4 \times 0.9 \pm 0.1 \mu \mathrm{m}$. The spores are oval to ellipsoidal, predominantly subterminal to terminal and distend the sporangium. The minimum and maximum temperatures tested for P118 growth are 15 and $40^{\circ} \mathrm{C}$, respectively (the optimum temperature for growth ranged from 25 to $32^{\circ} \mathrm{C}$ ). No growth occurs at 10 or $45^{\circ} \mathrm{C}$. P118 grows in TSB with $\mathrm{pH}$ varying from 5.0 to 9.5 (the optimum $\mathrm{pH}$ for growth ranged from 8-8.5). P118 grows in the presence of $2 \%$ $\mathrm{NaCl}$ but does not grow with $3 \% \mathrm{NaCl}$. Growth occurs in the presence of $0.001 \%$ lysozyme. The strain is facultative anaerobic and presents a Voges-Proskauer negative test. Nitrate is reduced to nitrite. Considering the results obtained using the API $50 \mathrm{CH}$ kit, acid is produced from L-arabinose, ribose, Dxylose, D-galactose, D-glucose, D-fructose, D-mannose, Dmannitol, amygdalin, arbutin, esculin, salicin, D-cellobiose, Dmaltose, lactose, melibiose, sucrose, trehalose, raffinose, gentibiose and D-turanose. Weak production of acid is observed when glycerol, D-arabinose and $\beta$ methyl-D-xyloside are the carbohydrates tested. No acid is observed from erythritol, L-xylose, adonitol, L-sorbose, L-rhamnose, dulcitol, inositol, D-sorbitol, $\alpha$ methyl-D-mannoside, $\alpha$ methyl-Dglucoside, N-acetil-glucosamine, inulin, melezitose, starch, glycogen, xylitol, D-lyxose, D-tagatose, D-fucose, L-fucose, D-arabitol, L-arabitol, gluconate, 2 keto-gluconate and 5 ketogluconate. Strain P118 is able to hydrolyze 1\% tween 80 and casein (weak test), but not gelatin. Does not utilize gluconate and caprate and produces urease.

Comparison of nearly complete $16 \mathrm{~S}$ rRNA gene sequence of strain P118 with those in GenBank indicated that the novel strain was phylogenetically related to members of the genus Paenibacillus. P118 displayed highest levels of 16S rRNA gene sequence similarity with $P$. amylolyticus NRRL NRS-290 (98.8\%), P. pabuli HSCC 492 (98.6\%), P. tundrae Ab10b (98.5\%), P. xylanexedens B22a (98.3\%) and P. tylopili MK2 (98.3\%). Phylogenetic tree constructed using the neighborjoining (Fig. 1) and maximum-parsimony methods were concordant with one another (not shown). P118 formed a cluster with the five above mentioned species. When other cellulolytic Paenibacillus species were used for comparison $(P$. campinasensis - (12); P. phyllosphaerae - (24); P. cellulosilyticus - (23); P. cellulositrophicus - (1); P. prosopidis - (35); P. pinihumi - (10); P. pini - (11); P. curdlanolyticus (21)) levels of $16 \mathrm{~S}$ rRNA gene sequence similarities were below 96\%. These species were included in the phylogenetic tree to demonstrate the distance between P118 and the recognized cellulolytic species (Fig. 1). No strain belonging to the five closest species to P118 has been described as able to degrade cellulose so far. 


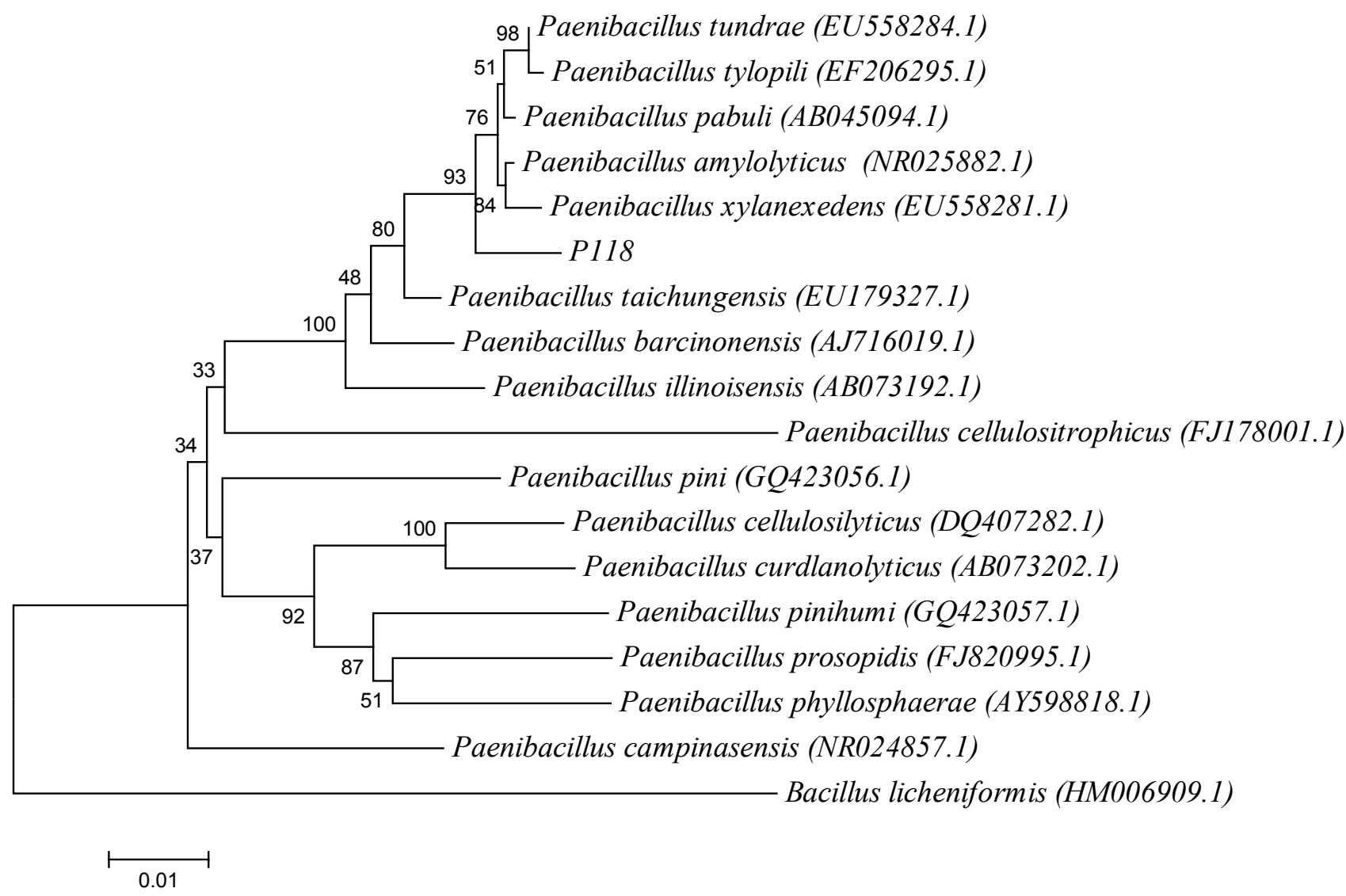

Figure 1. Phylogenetic tree obtained by the neighbor-joining method, based on the alignment of 16S rRNA of Paenibacillus sp. strain P118 and other 16 species from this genus. Bacillus licheniformis was used as an out-group. Bootstrap analyses were performed with 1,000 repetitions. Scale bar indicates the distance in substitutions per nucleotide.

Profiles of the major fatty acids of strain P118 are shown in Table 1. Anteiso- $\mathrm{C}_{15: 0}$, the major fatty acid in recognized members of the genus Paenibacillus, was also the major fatty acid component of strain P118 (38.73\%) followed by $\mathrm{C}_{16: 0}$ $(20.85 \%)$. For the menaquinone profile, the MK-7 was the predominant one and this is in agreement with the description of the Paenibacillus genus (2).

Table 2 shows the characteristics that differentiate strain P118 from the closest type strains of Paenibacillus chosen based on phylogenetic data (16S rRNA sequence). They clearly demonstrate that strain P118 does not match to any of these Paenibacillus species and may represent a novel species of the genus. It is important to highlight the $\mathrm{pH}$ range in which $\mathrm{P} 118$ grows and the resistance to lysozyme $(0.001 \%)$, besides its cellulolytic property. However, further studies, such as DNADNA hybridization, are still necessary to define a new species.

Table 1. Cellular fatty acid profiles (\%) of strain P118

\begin{tabular}{|c|c|}
\hline Fatty acid & \\
\hline Iso- $\mathrm{C}_{13: 0}$ & 0.21 \\
\hline Anteiso- $\mathrm{C}_{13: 0}$ & 0.25 \\
\hline Iso- $\mathrm{C}_{14: 0}$ & 5.24 \\
\hline $\mathrm{C}_{14: 0}$ & 12.36 \\
\hline Iso- $\mathrm{C}_{15: 0}$ & 8.53 \\
\hline Anteiso- $\mathrm{C}_{15: 0}$ & 38.73 \\
\hline $\mathrm{C}_{15: 0}$ & 0.58 \\
\hline Iso- $\mathrm{C}_{16: 0}$ & 3.93 \\
\hline $\mathrm{C}_{16: 1 \mathrm{w}} \mathrm{w1c}$ & 7.02 \\
\hline $\mathrm{C}_{16: 0}$ & 20.85 \\
\hline Iso- $\mathrm{C}_{17: 0}$ & 1.31 \\
\hline Anteiso- $\mathrm{C}_{17: 0}$ & 0.99 \\
\hline
\end{tabular}


Table 2. Some characteristics that differentiate strain P118 (isolated in this study) from the closest type strains of Paenibacillus chosen based on phylogenetic data (16S rRNA sequence)

\begin{tabular}{|c|c|c|c|c|c|c|}
\hline Characteristic & P118 & P. amylolyticus ${ }^{\mathrm{a}}$ & P. tundrae ${ }^{\mathrm{b}}$ & P. xylanexedens ${ }^{\mathrm{c}}$ & P. pabuli ${ }^{\mathrm{d}}$ & P. tylopili ${ }^{\mathrm{e}}$ \\
\hline Nitrate reduction & + & + & + & + & - & - \\
\hline \multicolumn{7}{|l|}{ Hydrolysis of: } \\
\hline Casein & $+\mathrm{w}$ & $+\mathrm{w}$ & nd & nd & $v^{*}$ & - \\
\hline Starch & - & + & nd & nd & + & + \\
\hline Gelatin & - & + & nd & nd & nd & - \\
\hline Tween $20(1 \% \mathrm{v} / \mathrm{v})$ & - & + & nd & nd & nd & nd \\
\hline \multicolumn{7}{|l|}{ Growth in the presence of: } \\
\hline $5 \% \mathrm{NaCl}$ & - & - & nd & nd & $v^{*}$ & $\mathrm{v}$ \\
\hline $0.001 \%$ lysozyme & + & - & nd & nd & - & nd \\
\hline \multicolumn{7}{|l|}{ Conditions for growth: } \\
\hline $\mathrm{pH}$ range & $5-9.5$ & $4.5-9$ & $5.2-8.8$ & $5.7-8.8$ & nd & $6-9$ \\
\hline pH optimum & $8-8.5$ & 7 & 6.4 & 6 & nd & 8 \\
\hline Temperature range $\left({ }^{\circ} \mathrm{C}\right)$ & $15-40$ & $10-40$ & $13-37$ & $13-32$ & $5-40$ & $9-40(v)$ \\
\hline Temperature optimum $\left({ }^{\circ} \mathrm{C}\right)$ & $25-30$ & 37 & 27 & 23 & $28-30$ & 25 \\
\hline Urease & + & - & nd & nd & - & - \\
\hline \multicolumn{7}{|l|}{ Acid production from: } \\
\hline L-arabinose & + & + & - & - & + & + \\
\hline D-xylose & + & + & + & - & + & + \\
\hline Inositol & - & + & - & - & nd & - \\
\hline D-sorbitol & - & - & + & - & - & nd \\
\hline$\alpha$-methyl D-glucoside & - & + & + & - & + & nd \\
\hline Lactose & + & - & + & + & + & + \\
\hline Inulin & - & + & + & - & + & nd \\
\hline Melezitose & - & + & + & - & + & nd \\
\hline Raffinose & + & - & + & + & + & + \\
\hline DNA G+C content $(\mathrm{mol} \%)$ & $45.8^{* *}$ & $46.3-46.6$ & 50.3 & 46.4 & $48-50$ & 44.3 \\
\hline Major cellular fatty acids & $\begin{array}{l}\text { anteiso- } \mathrm{C}_{15: 0} \\
\text { and } \mathrm{C}_{16: 0}\end{array}$ & $\begin{array}{l}\text { anteiso- } \mathrm{C}_{15: 0} \text { and } \\
\mathrm{C}_{16: 0}\end{array}$ & anteiso- $\mathrm{C}_{15: 0}$ & anteiso- $\mathrm{C}_{15: 0}$ & $\begin{array}{l}\text { anteiso- } \mathrm{C}_{15: 0} \\
\text { and } \mathrm{C}_{16: 0}\end{array}$ & anteiso- $\mathrm{C}_{15: 0}$ \\
\hline
\end{tabular}

nd, not determined; v, variable result; data from (a) Shida et al. (32), (b) and (c) Nelson et al. (20), (d) Nakamura (19) and Kuisiene et al. (13), (e) Kuisiene et al. (13). (*) type strain hydrolyzes casein and is inhibited by $5 \% \mathrm{NaCl}$; (**) Dr. Peter Schumann, DSMZ, Braunschweig, Germany determined the DNA base composition of P118 by HPLC (33).

Strain P118 showed to be a cellulolytic bacterium, able to produce CMCase (Fig. 2). The time-course fermentation profile, when CMC was the sole carbon source for P118 growth, indicates a maximum activity at the first day $(0.154 \mathrm{U} / \mathrm{ml})$. Data concerning cellulase activity in Paenibacillus are scarce in literature, and very often those available cannot be used for comparison since different conditions, methodology for enzymatic activity assays and units are used. However, our results were comparable to those obtained by Ko et al. (12) for P. campinasensis BL-11, which presented an activity of $0.1 \mathrm{U} / \mathrm{ml}$ in $\mathrm{LB}$ medium plus xylan oat spelts. Furthermore, P118 showed a higher cellulase activity than $P$. curdlanolyticus B-6 grown in Berg medium containing 0.5\% oat spelts (21). In fact, considering the biotechnological potential of P118, higher values for cellulase production can be found in literature for other bacterial genera, fungi and actinomycetes. However, it is important to consider that these values can be improved. When Semêdo et al. (31) first described the cellulolytic strain Streptomyces drozdowiczii M7a, its cellulase activity showed to be around $0.1 \mathrm{U} / \mathrm{ml}$. Changing the medium used and the culture conditions, an increase of 6 times in the enzyme production was observed (8). Moreover, it is important to state that P118 showed its maximal cellulase activity in the very first day of the experiment, which can be considered a very important characteristic for an economical point of view.

In conclusion, a novel and promising Paenibacillus strain isolated from $P$. maculicauda gut is now available for further studies aiming the optimization of its cellulase production, facilitating its potential use in industrial applications. 


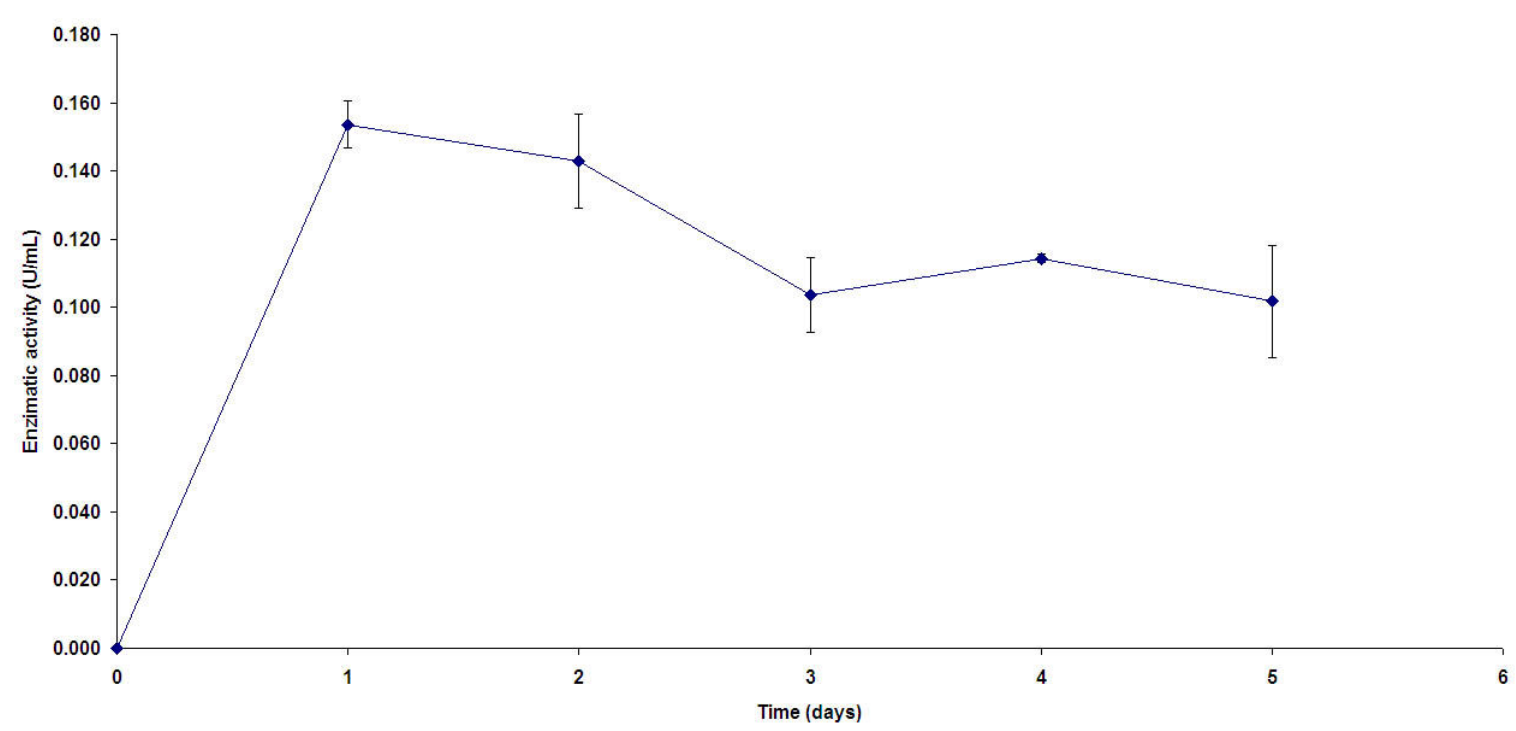

Figure 2. Carboxymethylcellulase (CMCase) activity at different periods of time. Results were expressed as the average of two replicates. One unit (U) of CMCase activity corresponded to $1 \mu \mathrm{mol}$ of glucose equivalent released per minute under the assay conditions.

\section{ACKNOWLEDGEMENTS}

This work was funded by the National Research Council of Brazil (CNPq), Financiadora de Estudos e Projetos (FINEP) and Fundação de Amparo à Pesquisa do Estado do Rio de Janeiro (FAPERJ).

\section{REFERENCES}

1. Akaracharanya, A.; Lorliam, W.; Tanasupawat, S.; Lee, K.C.; Lee, J.S. (2009). Paenibacillus cellulositrophicus sp. nov., a cellulolytic bacterium from Thai soil. Int. J. Syst. Evol. Microbiol. 59, 2680-2684.

2. Ash, C.; Priest F.G.; Collins, M.D. (1993). Molecular identification of rRNA group 3 bacilli (Ash, Farrow, Wallbanks and Collins) using a PCR probe test. Proposal for the creation of a new genus Paenibacillus. Antonie van Leeuwenhoek 64, 253-260.

3. Bairagi, A.; Sarkar Ghosh, K.; Sen, S.K.; Ray, A.K. (2002). Duckweed (Lemna polyrhiza) leaf meal as a source of feedstuff in formulated diets for rohu (Labeo rohita Ham.) fingerlings after fermentation with a fish intestinal bacterium. Bioresour Technol. 85, 17-24.

4. Casatti, L. (2002). Alimentação dos peixes de um riacho do Parque Estadual Morro do Diabo, bacia do alto Rio Paraná, sudeste do Brasil.
Biota Neotrop. 2, 1-14.

5. Garavello, J.C. (1977). Systematics and geographical distribution of the genus Parotocinclus, Eigenmann \& Eigenmann, 1889 (Ostariophysi, Loricariidae). Arq. Zool. S. Paulo 28, 1-37.

6. Ghose, T.K. (1987). Measurement of cellulase activities. Pure Appl. Chem. 59, 257-268.

7. Gordon, R.E.; Haynes, W.C.; Pang, C.H. (1973). The genus Bacillus. Agriculture Handbook no. 427. U.S. Department of Agriculture, Washington, D.C.

8. Grigorevski de Lima, A.L.; Pires do Nascimento, R.; da Silva Bon, E.P.; Coelho, R.R.R. (2005). Streptomyces drozdowiczii cellulase production using agro-industrial by-products and its potential use in the detergent and textile industries. Enzyme Microb. Technol. 37, 272-277.

9. Hansen, G.H.; Olafsen, J.A. (1999). Bacterial interactions in early life stages of marine cold water fish. Microb. Ecol. 38, 1-26.

10. Kim, B.C.; Lee, K.H.; Kim, M.N.; Kim, E.M.; Rhee, M.S.; Kwon, O.Y.; Shin, K.S. (2009a). Paenibacillus pinihumi sp. nov., a cellulolytic bacterium isolated from the rhizosphere of Pinus densiflora. J. Microbiol. 47, 530-535.

11. Kim, B.C.; Lee, K.H.; Kim, M.N.; Kim, E.M.; Min, S.R.; Kim, H.S.; Shin, K.S. (2009b). Paenibacillus pini sp. nov., a cellulolytic bacterium isolated from the rhizosphere of pine tree. J. Microbiol. 47, 699-704.

12. Ko, C.H.; Chen, W.L.; Tsai, C.H.; Jane, W.N.; Liu, C.C.; Tu, J. (2007). Paenibacillus campinasensis BL11: a wood material-utilizing bacterial 
strain isolated from black liquor. Bioresour. Technol. 98, 2727-2733.

13. Kuisiene, N.; Raugalas, J.; Spröer, C.; Kroppenstedt, R.M.; Stuknyte, M.; Chitavichius, D. (2008). Paenibacillus tylopili sp. nov., a chitinolytic bacterium isolated from the mycorhizosphere of Tylopilus felleus. Folia Microbiol. 53, 433-437.

14. Kumar, R.; Singh, S.; Singh, O.V. (2008). Bioconversion of lignocellulosic biomass: biochemical and molecular perspectives. J. Ind. Microbiol. Biotechnol. 35, 377-391.

15. Kumar, S.; Tamura, K.; Nei, M. (1993). MEGA: Molecular evolutionary genetics analysis, version 1.0. The Pennsylvania State University, PA.

16. Leitão, R.P.; Caramaschi, E.P.; Zuanon, J. (2007). Following food clouds: feeding association between a minute loricariid and a characidiin species in an Atlantic Forest stream, Southeastern Brazil. Neotrop. Ichthyol. 5, 307-310.

17. Massol-Deya, A.A.; Odelson, D.A.; Hickey, R.F.; Tiedje, J.M. (1995) Bacterial community fingerprinting of amplified $16 \mathrm{~S}$ and $16-23 \mathrm{~S}$ ribosomal DNA gene sequences and restriction endonuclease analysis (ARDRA), In: Akkermans, A.D.L. van Elsas, J.D., de Bruijn F.J. (Eds.), Molecular Microbial Ecology Manual, Kluwer Academic Publishers, The Netherlands, pp. 3.3.2: 1-8.

18. Miller, L. (1959). Use of dinitrosalicylic acid reagent for determination of reducing sugar. Anal. Chem. 31, 426-428.

19. Nakamura, L.K. (1984). Bacillus amylolyticus sp. nov., nom. rev., Bacillus lautus sp. nov., nom. rev., Bacillus pabuli sp. nov., nom. rev., and Bacillus validus sp. nov., nom. rev. Int. J. Syst. Bacteriol. 34, 224 226.

20. Nelson, D.M.; Glawe, A.J.; Labeda, D.P.; Cann, I.K.O.; Mackie, R.I. (2009). Paenibacillus tundra sp. nov. and Paenibacillus xylanexedens sp. nov., psychrotolerant, xylan-degrading bacteria from Alaskan tundra. Int. J. Syst. Evol. Microbiol. 59, 1708-1714.

21. Pason, P.; Kyu, K.L.; Ratanakhanokchai, K. (2006). Paenibacillus curdlanolyticus strain B-6 xylanolytic-cellulolytic enzyme system that degrades insoluble polysaccharides. Appl. Environ. Microbiol. 72, 24832490.

22. Rastogi, G.; Muppidi, G.L.; Gurram, R.N.; Adhikari, A.; Bischoff, K.M.; Hughes, S.R.; Apel, W.A.; Bang, S.S.; Dixon, D.J.; Sani, R.K. (2009). Isolation and characterization of cellulose-degrading bacteria from the deep subsurface of the Homestake gold mine, Lead, South Dakota, USA. J. Ind. Microbiol. Biotechnol. 36, 585-598.

23. Rivas, R.; García-Fraile, P.; Mateos, P.F.; Martínez-Molina, E.; Velázquez, E. (2006). Paenibacillus cellulosilyticus sp. nov., a cellulolytic and xylanolytic bacterium isolated from the bract phyllosphere of Phoenix dactylifera. Int. J. Syst. Evol. Microbiol. 56,
2777-2781.

24. Rivas, R.; Mateos, P.F; Martínez-Molina, E.; Velázquez, E. (2005). Paenibacillus phyllosphaerae sp. nov., a xylanolytic bacterium isolated from the phyllosphere of Phoenix dactylifera. Int. J. Syst. Evol. Microbiol. 55, 743-746.

25. Saitou, N.; Nei, M. (1987). The neighbor-joining method: A new method for reconstructing phylogenetic trees. Mol. Biol. Evol. 4, 406-425.

26. Sambrook, J.; Fritsch, E.F.; Maniatis, T. (1989). Molecular Cloning: a Laboratory Manual, 2nd edn. Cold Spring Harbor Laboratory, Cold Spring Harbor, New York.

27. Schaefer, S.A. (2003). Loricariidae - Hypoptopomatinae (Armored catfishes). In: Reis, A.R.E.; Kullander, S.O.; Ferraris, Jr., C.J. (eds.), Checklist of the fresh- water fishes of South and Central America. EDIPUCRS, Porto Alegre, Brasil, p. 321-329.

28. Seldin, L.; Rosado, A.S.; da Cruz, D.W.; Nobrega, A.; van Elsas J.D.; Paiva, E. (1998). Comparison of Paenibacillus azotofixans strains isolated from rhizoplane, rhizosphere, and non-root-associated soil from maize planted in two different brazilian soils. Appl. Environ. Microbiol. 64, 3860-3868.

29. Seldin, L.; Dubnau, D. (1985). DNA homology among Bacillus polymyxa, Bacillus macerans, Bacillus azotofixans and other nitrogen fixing Bacillus strains. Int. J. Syst. Bacteriol. 35, 151-154.

30. Seldin, L.; Penido, E.G.C. (1986). Identification of Bacillus azotofixans using API tests. Antonie van Leeuwenhoek 52, 403-409.

31. Semêdo, L.T.; Gomes, R.C.; Bon, E.P.; Soares, R.M.; Linhares, L.F.; Coelho, R.R. (2000). Endocellulase and exocellulase activities of two Streptomyces strains isolated from a forest soil. Appl. Biochem. Biotechnol. 84-86, 267-276.

32. Shida, O.; Takagi, H.; Kadowaki, K.; Nakamura, L.K.; Komagata, K. (1997). Emended description of Paenibacillus amylolyticus and description of Paenibacillus illinoisensis sp. nov. and Paenibacillus chibensis sp. nov. Int. J. Syst. Bacteriol. 47, 299-306.

33. Tamaoka, J.; Komagata, K. (1984). Determination of DNA base composition by reverse-phase high-performance liquid chromatography. FEMS Microbiol. Lett. 25, 125-128.

34. Thompson, J.D.; Gibson, T.J.; Plewniak, F.; Jeanmougin, F.; Higgins, D.G. (1997). The CLUSTAL_X windows interface: flexible strategies for multiple sequence alignment aided by quality analysis tools. Nucleic Acids Res. 25, 4876-4882.

35. Valverde, A.; Fterich, A.; Mahdhi, M.; Ramírez-Bahena, M.H.; Caviedes, M.A.; Mars, M.; Velázquez, E.; Rodriguez-Llorente, I.D. (2010). Paenibacillus prosopidis sp. nov., isolated from the nodules of Prosopis farcta. Int. J. Syst. Evol. Microbiol. 60, 2182-2186. 